\title{
Crowd-Sourced Cartography to Visualise the Forgotten: Mapping Britain's Corpse Roads
}

\author{
Stuart Dunn \\ Department of Digital Humanities, \\ King's College, London \\ 26-29 Drury Lane, London WC2B 5RL \\ stuart.dunn@kcl.ac.uk
}

\section{INTRODUCTION}

\begin{abstract}
Now it is the time of night
That the graves all gaping wide

Every one lets forth its sprite

In the church-way paths to glide
\end{abstract}

Thus speaks Puck in A Midsummer Night's Dream (Act V Scene 1). The reference is to the ad hoc network of 'corpse roads' which sprang up across Britain in the medieval period, when one of the primary means parish churches had of maintaining their control over outlying settlements was to insist on burials in their own consecrated grounds. Thus, funeral processions from the outlying areas had to go across country with the coffin. In many areas these routes took on great folkloric significance; and as late as the early twentieth century it was still (erroneously) believed that if a coffin passed over private land then the path it took became a public right of way.

Most historians regard corpse roads as a minor detail in ecclesiastical or social history; and today detailed discussion of them is primarily the domain of myth hunters (and of course long distance walkers). This Participatory GIS project seeks to gather as much information as possible on corpse roads, compile a definitive database, and publish a GIS-compatible dataset to attempt new analyses of corpse roads' historical and geographical development. They are important manifestations of social networks, and the motivation here is to see what 'digital humanities' can bring to a class of historical data which has hitherto been regarded as somewhat prosaic.

This paper will set out the methodology used to record and map the corpse roads' routes (currently the database contains over a hundred routes across England and Scotland), and will present the map thus formed. It will critique how effective a conventional map visualisation is for the presentation of such disparate and fuzzy information, and focus on how such a map can tell the very local stories that constitute such data. To achieve this, individual cases will be highlighted which illustrate the difficulties of visualising such routes which live on in the contemporary landscape in very different forms. Examples include the Schap road in Cumbria, which is extensively documented on Flickr as it is now a long-distance walking route; the Eskdale route in the Lake District which features in a late nineteenth century American travelogue, or the route ending at St Pancras Parish Church in London, which lives on only in street names.

From the time of Shakespeare's Puck, corpse roads have inspired narrative and metaphor. This paper will illustrate how a visual 'deep mapping' approach can be used to illustrate and understand those narratives.

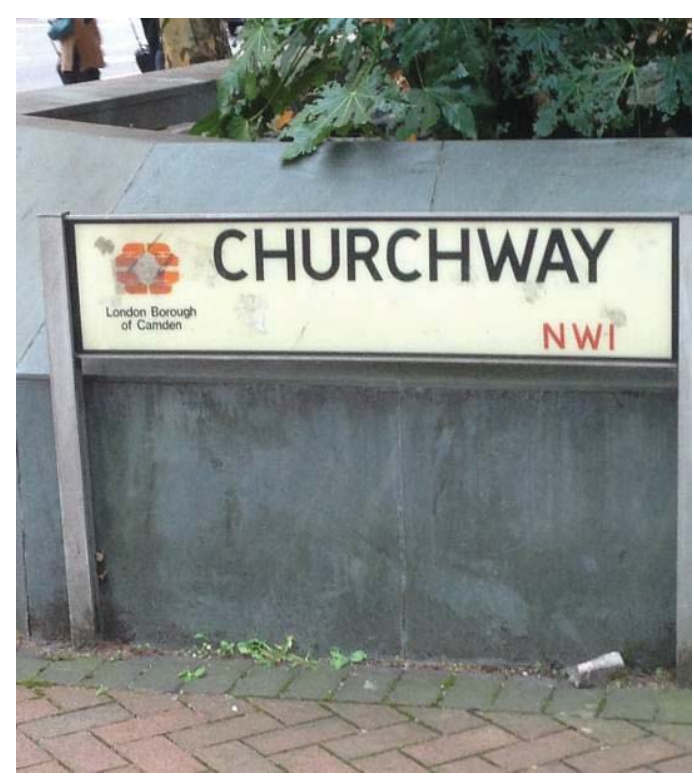

Figure 1: Street name in Euston, London 